\title{
Picky eating dan status gizi pada anak prasekolah
}

\author{
Rahma Hardianti, Fillah Fithra Dieny", Hartanti Sandi Wijayanti
}

\begin{abstract}
Background: Picky eater tended to reject new or unfamiliar foods. They had preferred food that lead to less food intake diversity. Futhermore, inadequate variation and amount of food intake could distrupt the growth of children.

Objective : To determine the correlation between picky eating and nutritional status in preschool children.

Methods : This was an observational studies with cross sectional design. Sixty-three subjects were randomly selected based on the inclusion criteria. Data collected included socio-demographic information. Picky eating was obtained through the Children's Eating Behavior Questionnaire. Nutritional status was measured based on weight-for-height z-score (WHZ), weight-for-age zscore (WAZ), and height-for-age z-score (HAZ).Nutrition intake was assessed by $2 \times 24$ h dietary recall. Physical activity was obtained using Early Years-Physical Activity Questionnaire. Data were analyzed using Chi-square and Fisher's test.

Results : The prevalence of picky eater was $52.4 \%$ in preschoolers. WHZ, WAZ, and HAZ mean were $-0.3 \pm 1.5 S D,-0.2 \pm 1.3 S D$, and HAZ -0.2 $\pm 1.3 S D$, respectively. Picky eating was associated with carbohydrate and fiber intake (p<0.05). There was no correlation between picky eating and nutritional status of WHZ, WAZ and HAZ (p>0.05). Meanwhile, food intake associated with nutritional status of $B B / U$ was energy, protein and fat intake $(p<0.05)$.
\end{abstract}

Conclusion : There was no relation between picky eating with nutritional status of WHZ, WAZ and HAZ in preschool children.

Key Words : picky eating, nutritional status, preschool

\section{ABSTRAK}

Latar Belakang : Picky eater cenderung menolak makanan baru atau tidak familiar serta memiliki preferensi makan yang menyebabkan asupan makanan kurang bervariasi. Ketidakcukupan variasi dan jumlah asupan makan jika dibiarkan dapat mengganggu pertumbuhan anak.

Tujuan : Mengetahui hubungan picky eating dengan status gizi pada anak prasekolah.

Metode : Penelitian observasional dengan rancangan cross-sectional. Enam puluh tiga subjek dipilih secara acak berdasarkan kriteria inklusi. Data yang dikumpulkan yaitu informasi sosio-demografi. Picky eating diperoleh melalui Children Eating Behavior Questionnaire.Status gizi dikategorikan berdasarkan z-score berat badan menurut tinggi badan (BB/TB), berat badan menurut umur (BB/U) dan tinggi badan menurut umur (TB/U). Data asupan diperoleh melalui Food Recall $2 x 24 h$. Aktivitas fisik diperoleh dengan Early Years-Physical Activity Questionnaire. Data dianalisis menggunakan uji Chi-square dan Fisher's.

Hasil : Persentase picky eater sebanyak 52,4\% dari total subjek. Rerata z-score BB/TB, BB/U, dan TB/U yaitu -0,3 $\pm 1,3 S D$, -

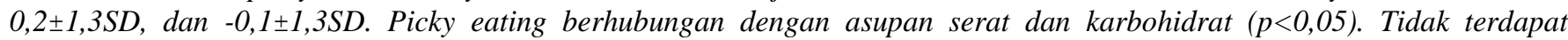
hubungan picky eating dengan status gizi $(p>0,05)$. Sementara itu, asupan makanan yang berhubungan dengan status gizi BB/U adalah asupan energi, protein dan lemak $(p<0,05)$.

Simpulan : Tidak terdapat hubungan picky eating dengan status gizi BB/TB, BB/U dan TB/U pada anak prasekolah.

Kata Kunci : picky eating , status gizi, prasekolah

\section{PENDAHULUAN}

Usia prasekolah merupakan fase yang membutuhkan status gizi baik untuk menunjang pertumbuhan dan perkembangan baik fisik, kecerdasan, dan emosional. ${ }^{1}$ Namun, kejadian kurang gizi, pendek dan kurus masih menjadi masalah pada anak yang nantinya dapat mempengaruhi tumbuh kembang. Picky eating merupakan salah satu risiko anak dapat mengalami kurang gizi, karena picky eater cenderung memiliki asupan energi, protein, karbohidrat, vitamin dan mineral lebih rendah dibandingkan non-picky eater. ${ }^{2}$

Departemen Ilmu Gizi, Fakultas Kedokteran, Universitas Diponegoro. Jl. Prof. H. Soedarto, Tembalang, Semarang 50275

"Korespondensi : e-mail: fillahdieny@gmail.com
Picky eater mengonsumsi asupan makan yang kurang bervariasi dan biasanya rendah sayuran, buah, makanan kaya protein dan serat karena penolakan terhadap makanan. ${ }^{3}$ Makanan yang disukai dan tidak disukai memiliki peran penting dalam pemilihan makan, dimana picky eater dapat menunjukkan adanya preferensi kuat terhadap makanan. ${ }^{4}$ Picky eating adalah fase perkembangan normal. ${ }^{1}$ Namun, hasil penelitian menyebutkan tiga perempat anak picky eater mulai menolak makanan pada tahun pertama kehidupan sampai usia dua tahun, puncaknya pada usia 2-6 tahun dan selanjutnya sesuai pertumbuhan individual, sehingga bila terus berlanjut akan diikuti berat badan yang kurang. ${ }^{5}$

Anak picky eater cenderung memiliki status gizi kurang. Anak picky eater lebih berisiko memiliki berat badan kurang, kenaikan berat badan inadekuat dan kekurangan zat gizi. ${ }^{3,6}$ Picky eater memiliki nilai 
Z-score berat badan menurut umur $(\mathrm{BB} / \mathrm{U})$, tinggi badan menurut umur $(\mathrm{TB} / \mathrm{U})$ dan berat badan menurut tinggi badan $(\mathrm{BB} / \mathrm{TB})$ lebih rendah dibandingkan nonpicky eater. ${ }^{2}$ Asupan makanan inadekuat baik zat gizi makro dan mikro memiliki peran penting dalam perlambatan pertumbuhan tinggi badan anak. ${ }^{7}$

Angka kejadian picky eating terus mengalami peningkatan. Penelitian di San Fransisco tahun 2010 menemukan kejadian picky eating tertinggi pada anak umur diatas 2 tahun sebanyak 13-22\%. ${ }^{8}$ Penelitian sebelumnya di Indonesia menunjukkan angka kejadian picky eating yang tinggi. Tahun 2009 di Palembang dan bekasi ditemukan masing masing 59,3\% dan 70,5\% anak mengalami picky eating. ${ }^{9,10}$ Penelitian di Riau tahun 2015 diketahui anak yang mengalami picky eating sebanyak 35,4\%.11 Penelitian di Semarang ditemukan 60,3\% anak mengalami picky eating. ${ }^{12}$

Picky eating sebagai salah satu perilaku makan yang mempengaruhi status gizi. Permasalahan gizi tidak hanya status gizi kurang tetapi anak pendek dan kurus juga dapat mempengaruhi tumbuh kembang anak. Menurut beberapa penelitian jika picky eating pada anak tidak segera ditangani akan memberikan efek, seperti inadekuat zat gizi tertentu yang akan berakibat pada status gizi. ${ }^{13,14}$

Di Indonesia, prevalensi balita gizi kurang masih cukup tinggi. Pada tahun 2013 terdapat 19,6\% balita kekurangan gizi yang terdiri dari 5,7\% balita dengan gizi buruk dan $13,9 \%$ berstatus gizi kurang. Jika dibandingkan dengan angka prevalensi nasional tahun $2007(18,4 \%)$ dan tahun $2010(17,9 \%)$ terlihat meningkat. ${ }^{15}$ Kota Semarang memiliki balita kekurangan gizi yang terdiri dari $2,73 \%$ balita dengan gizi kurang dan 0,38\% status gizi buruk. Jumlah balita berstatus gizi kurang di kecamatan Banyumanik tepatnya puskesmas Ngesrep termasuk tinggi Kota Semarang yaitu $2,88 \% .{ }^{16}$ Oleh karena itu, penelitian ini diharapkan dapat diketahui apakah terdapat hubungan picky eating dengan status gizi pada anak prasekolah di Indonesia, khususnya di Kecamatan Banyumanik, Semarang.

\section{BAHAN DAN METODE}

Penelitian ini termasuk dalam ruang lingkup keilmuan gizi khususnya gizi masyarakat. Jenis penelitian yang dilakukan yaitu analitik observasional dengan rancangan cross-sectional. Populasi terjangkau dalam penelitian ini adalah anak usia 36-60 bulan di Kelompok Bermain/Taman Kanak-kanak (KB/TK) Kecamatan Banyumanik, Kota Semarang. Pemilihan subjek anak prasekolah usia 36-60 bulan dikarenakan angka kejadian picky eating tertinggi terjadi pada fase ini. Balita yang memenuhi kriteria inklusi di KB/TK akan dipilih menjadi subjek penelitian dengan simple random sampling.
Kriteria inklusi dalam penelitian ini yaitu anak yang orang tuanya bersedia menandatangani informed consent, umur 36-60 bulan, tidak menderita sakit, seperti diare kronis (lebih dari 2 minggu), anorexia, diabetes melitus, penyakit ginjal kronis, penyakit jantung, kanker, tidak pasca operasi seperti operasi pada jantung, usus, ginjal dan atau sedang menderita kondisi patologi lain dalam waktu jangka panjang yang mengganggu asupan makanan. Kriteria eksklusi adalah anak pindah/putus sekolah atau mengundurkan diri saat penelitian berlangsung. Besar subjek penelitian dihitung dengan rumus analitis tidak berpasangan kategorik dan dibutuhkan sebanyak 57 orang dengan estimasi drop out $10 \%$ menjadi 63 orang. Subjek dipilih secara simple random sampling dari 149 anak yang dilakukan skrining terdapat 86 anak memenuhi kriteria inklusi. Selanjutnya, dipilih subjek sebanyak 63 anak.

Variabel bebas penelitian ini adalah picky eating. Penentuan picky eating pada anak menggunakan kuisioner yang diadopsi dari Child's Eating Behavior Questionnaire. Kuisioner diisi oleh enumerator dan dibacakan kepada ibu atau pengasuh anak. Terdapat 6 kategori dengan 5-7 pertanyaan setiap kategorinya. Jawaban terdiri dari tidak pernah, jarang, kadangkadang, sering, dan selalu dengan skala likert (skala 15). Total skoring dari kuisioner dikategorikan picky eating bila jumlah total skor food avoidant lebih tinggi daripada skor food approach dan sebaliknya pada kategori non-picky eating. ${ }^{17,18}$

Variabel terikat adalah status gizi dengan indikator berat badan menurut tinggi badan (BB/TB), berat badan menurut umur $(\mathrm{BB} / \mathrm{U})$ dan tinggi badan menurut umur (TB/U). Status gizi ditentukan dari data antropometri tinggi badan dan berat badan, kemudian diinterpretasikan dalam bentuk z-score menggunakan software komputer WHO Antro. Cut-off point indikator $\mathrm{BB} / \mathrm{U}$ gizi kurang $-3 \mathrm{SD} \mathrm{s} / \mathrm{d}<-2 \mathrm{SD}$, gizi baik $-2 \mathrm{SD}$ s/d $+2 \mathrm{SD}$ dan gizi lebih $>+2 \mathrm{SD}$. Indikator TB/U yaitu pendek $-3 \mathrm{SD} \mathrm{s} / \mathrm{d}<-2 \mathrm{SD}$, normal $\leq-2 \mathrm{SD}$ dan tinggi $>+2 \mathrm{SD}$. Indikator $\mathrm{BB} / \mathrm{TB}$ yaitu kurus $-3 \mathrm{SD} \mathrm{s} / \mathrm{d}<-2 \mathrm{SD}$, normal $-2 \mathrm{SD}$ s/d $+2 \mathrm{SD}$ dan gemuk $>+2 \mathrm{SD} .^{19}$

Variabel perancu yaitu asupan makan (energi, karbohidrat, lemak, protein, serat) dan aktivitas fisik. Data asupan diperoleh melalui wawancara pada ibu dengan food recall 3 x 24 jam meliputi hari aktif dan hari libur. Data asupan energi, karbohidrat, lemak, protein dan serat merupakan rata-rata dalam gram/hari dibandingkan dengan kebutuhan gizi harian. Asupan energi, karbohidrat, lemak dan protein menggunakan perhitungan masing-masing individu, sedangkan serat menggunakan Angka Kecukupan Gizi. Asupan terkategori baik apabila $>80 \%$ dan terkategori kurang $<80 \%$ asupan harian. ${ }^{20,21}$ Aktivitas fisik dinilai menggunakan pedoman kuisioner Early Year-Physical Activity Questionnaire (EY-PAQ). Kategori aktivitas 
kurang jika waktu anak bergerak aktif $<180$ menit/hari, sedangkan kategori aktivitas cukup jika mencapai $\geq 180$ menit/hari. ${ }^{22}$ Pengolahan dan analisis data menggunakan program komputer. Analisis univariat dilakukan untuk melihat gambaran karakteristik subjek penelitian. Analisis bivariat menggunakan uji chisquare dan apabila tidak terpenuhi, maka digunakan uji Fisher's untuk menganalisis hubungan picky eater dengan status gizi.

\section{HASIL}

Karakteristik subjek terlihat pada Tabel 1 yang menunjukkan rerata aktivitas fisik termasuk aktif, tetapi masih ada subjek terkategori aktivitas fisik rendah (90 menit/hari). Rerata indikator status gizi dengan z-score $\mathrm{BB} / \mathrm{TB}, \mathrm{BB} / \mathrm{U}$ dan $\mathrm{TB} / \mathrm{U}$ termasuk normal. Namun, data nilai minimal dan maksimal terlihat masih ada anak yang terkategori gizi kurang hingga gizi lebih. Rerata persentase asupan terlihat persentase asupan energi, protein, lemak dan karbohidrat sudah memenuhi kebutuhan anak, tetapi masih ada subjek yang memiliki persentase asupan kurang hingga lebih. Berbeda pada rerata asupan serat yang belum memenuhi kebutuhan harian anak. Kisaran konsumsi serat sangat bervariasi, ada anak yang mengonsumsi 1 gram/hari hingga 21,4 gram/hari.

Tabel 2 menunjukkan anak yang mengalami picky eating terdapat 33 anak, 18 anak diantaranya adalah perempuan. Jumlah anak laki-laki dan perempuan berstatus kurus $\mathrm{BB} / \mathrm{U}$ memiliki jumlah yang sama yaitu 2 orang. Pada indikator BB/TB dan TB/U jumlah anak laki-laki kurus dan pendek berbeda 1 orang dibandingkan perempuan. Jumlah total anak aktif mencapai $69,8 \%$ dan aktivitas fisik kurang lebih tinggi pada perempuan daripada laki-laki. Anak lakilaki lebih banyak yang memiliki asupan energi, protein, lemak, dan karbohidrat kurang dibandingkan perempuan. Namun, asupan serat yang kurang lebih banyak pada anak perempuan $(44,5 \%)$ dibandingkan laki laki $(39,7 \%)$.

Tabel 3 menunjukkan hubungan kategori picky eating dengan asupan energi, protein, lemak, karbohidrat dan serat. Hasil penelitian ditemukan bahwa asupan energi, protein, lemak, karbohidrat, dan serat yang termasuk kategori kurang lebih banyak terjadi pada anak picky eater dibandingkan non-picky eater. Berdasarkan hasil uji bivariat tidak ditemukan adanya hubungan antara asupan energi, protein, dan lemak dengan picky eating ( $>>0,05)$. Asupan karbohidrat dan serat menunjukkan adanya hubungan dengan kategori picky eating $(\mathrm{p}<0,05)$.

Tabel 4 menunjukkan hubungan picky eating dengan status gizi. Hasil penelitian menunjukkan bahwa anak pendek lebih banyak terjadi pada anak picky eater dibandingkan non-picky eater yaitu sebesar $9,1 \%$. Berdasarkan uji bivariat tidak ditemukan adanya hubungan antara picky eating dengan status gizi berdasarkan BB/TB, BB/U dan TB/U (p>0,05).

Pada Tabel 5 diketahui bahwa tidak terdapat hubungan asupan energi, protein, lemak, karbohidrat, serat dan aktivitas fisik dengan status gizi $\mathrm{BB} / \mathrm{TB}$. Berdasarkan hasil uji bivariat ditemukan adanya hubungan antara asupan energi, protein, dan lemak dengan status gizi $B B / U(p<0,05)$. Namun, pada asupan karbohidrat, serat dan aktivitas fisik tidak ditemukan adanya hubungan dengan status gizi $B B / U(p>0,05)$. Selain itu, tidak ditemukan hubungan asupan energi, protein, lemak, karbohidrat, serat dan aktivitas fisik dengan status gizi TB/U ( $>>0,05)$.

Tabel 1. Nilai Rerata dan Standar Deviasi, Minimal, dan Maksimal Data Indikator Status Gizi dan Asupan

\begin{tabular}{|c|c|c|c|c|}
\hline Variabel & Rerata \pm SD & Median & Minimal & Maksimal \\
\hline Usia (bulan) & $50,7 \pm 7,7$ & 53 & 36 & 60 \\
\hline Berat Badan (kg) & $16,7 \pm 3,4$ & 16 & 10,8 & 27 \\
\hline Tinggi Badan $(\mathrm{cm})$ & $104,7 \pm 7,8$ & 105 & 85,6 & 117,8 \\
\hline Aktivitas Fisik (menit/hari) & $221,6 \pm 64,8$ & 240 & 90 & 342 \\
\hline \multicolumn{5}{|l|}{ Indikator Status Gizi } \\
\hline z-skor BB/TB & $-0,3 \pm 1,3$ & $-0,4$ & $-3,2$ & 3,8 \\
\hline z-skor BB/U & $-0,2 \pm 1,2$ & $-0,3$ & $-2,6$ & 3,0 \\
\hline z-skor TB/U & $-0,1 \pm 1,3$ & $-0,2$ & $-2,9$ & 2,8 \\
\hline \multicolumn{5}{|l|}{ Asupan } \\
\hline Energi (kkal) & $1478 \pm 287$ & 1455 & 844 & 1993 \\
\hline Protein $(\mathrm{g})$ & $53,1 \pm 13,7$ & 52,2 & 28 & 84,2 \\
\hline Lemak $(\mathrm{g})$ & $54,6 \pm 15,1$ & 55 & 25,1 & 86,8 \\
\hline Karbohidrat (g) & $192,2 \pm 39,3$ & 188,7 & 107,8 & 272,2 \\
\hline Serat $(\mathrm{g})$ & $7,9 \pm 5,2$ & 6,3 & 1 & 21,4 \\
\hline \multicolumn{5}{|l|}{ Persentase Kecukupan Asupan } \\
\hline Energi $(\%)$ & $88,2 \pm 19,1$ & 88,4 & 53,2 & 141,1 \\
\hline Protein $(\%)$ & $84,8 \pm 24,3$ & 80,7 & 41,9 & 169,1 \\
\hline Lemak (\%) & $98 \pm 30,2$ & 95,8 & 48,1 & 188,4 \\
\hline Karbohidrat (\%) & $83,4 \pm 17,9$ & 80,7 & 50,1 & 123,6 \\
\hline Serat $(\%)$ & $39,1 \pm 26,2$ & 33 & 5,7 & 107,8 \\
\hline
\end{tabular}


Tabel 2. Karakteristik Subjek Penelitian

\begin{tabular}{|c|c|c|c|c|c|c|}
\hline \multirow{2}{*}{ Variabel } & \multicolumn{2}{|c|}{ Laki-laki } & \multicolumn{2}{|c|}{ Perempuan } & \multicolumn{2}{|c|}{ Total } \\
\hline & n & $\%$ & n & $\%$ & $\mathbf{n}$ & $\%$ \\
\hline \multicolumn{7}{|l|}{ Kategori Picky eating } \\
\hline Picky eating & 15 & 48,4 & 18 & 56,2 & 33 & 52,4 \\
\hline Non-picky eating & 16 & 51,6 & 14 & 43,8 & 30 & 47,6 \\
\hline \multicolumn{7}{|l|}{ Indikator $\mathrm{BB} / \mathrm{TB}$} \\
\hline Kurus & 2 & 6,5 & 3 & 9,4 & 5 & 7,9 \\
\hline Normal & 28 & 90,3 & 27 & 94,4 & 55 & 92,1 \\
\hline Overweight & 1 & 3,2 & 2 & 6,2 & 3 & 4,8 \\
\hline \multicolumn{7}{|l|}{ Indikator $\mathrm{BB} / \mathrm{U}$} \\
\hline Kurang & 2 & 6,5 & 2 & 6,2 & 4 & 6,4 \\
\hline Baik & 28 & 90,3 & 28 & 87,5 & 56 & 88,9 \\
\hline Lebih & 1 & 3,2 & 2 & 6,2 & 3 & 4,8 \\
\hline \multicolumn{7}{|l|}{ Indikator TB/U } \\
\hline Pendek & 3 & 9,7 & 2 & 6,2 & 5 & 7,9 \\
\hline Normal & 26 & 83,9 & 28 & 87,5 & 54 & 85,7 \\
\hline Tinggi & 2 & 6,5 & 2 & 6,2 & 4 & 6,3 \\
\hline \multicolumn{7}{|l|}{ Aktivitas Fisik } \\
\hline Kurang & 7 & 22,6 & 12 & 37,5 & 19 & 30,2 \\
\hline Aktif & 24 & 77,4 & 20 & 62,5 & 44 & 69,8 \\
\hline \multicolumn{7}{|l|}{ Asupan Energi } \\
\hline Kurang & 14 & 28,1 & 9 & 45,2 & 23 & 36,5 \\
\hline Baik & 13 & 59,4 & 19 & 41,9 & 32 & 50,8 \\
\hline Lebih & 4 & 12,5 & 4 & 12,9 & 8 & 12,7 \\
\hline \multicolumn{7}{|l|}{ Asupan Protein } \\
\hline Kurang & 10 & 32,3 & 5 & 15,6 & 15 & 23,8 \\
\hline Baik & 21 & 67,7 & 27 & 84,4 & 48 & 76,2 \\
\hline \multicolumn{7}{|l|}{ Asupan Lemak } \\
\hline Kurang & 11 & 35,5 & 7 & 21,9 & 18 & 28,6 \\
\hline Baik & 14 & 45,2 & 18 & 56,2 & 32 & 50,8 \\
\hline Lebih & 6 & 19,4 & 7 & 21,9 & 13 & 20,6 \\
\hline \multicolumn{7}{|l|}{ Asupan Karbohidrat } \\
\hline Kurang & 17 & 54,8 & 16 & 50 & 33 & 53,4 \\
\hline Baik & 13 & 41,9 & 15 & 46,9 & 28 & 44,4 \\
\hline Lebih & 1 & 3,2 & 1 & 3,1 & 2 & 3,2 \\
\hline \multicolumn{7}{|l|}{ Asupan Serat } \\
\hline Kurang & 25 & 80,6 & 28 & 87,5 & 53 & 84,1 \\
\hline Baik & 6 & 19,4 & 4 & 12,5 & 10 & 15,9 \\
\hline
\end{tabular}

\section{PEMBAHASAN}

Proporsi angka kejadian picky eating anak prasekolah pada penelitian ini mencapai $52,4 \%$. Hasil penelitian ini memiliki angka kejadian yang tidak jauh berbeda dengan penelitian sebelumnya yaitu $54 \%$ di China $^{23}$ dan $60,3 \%$ di Indonesia. ${ }^{12}$ Angka kejadian yang tinggi dikarenakan picky eating sebagai fase normal pada anak prasekolah. Namun, kebanyakan orang tua khawatir saat anak mengonsumsi makanan yang tidak sehat, pilih-pilih dan sedikit, sehingga orang tua cenderung menganggap anak sebagai picky eater. ${ }^{24}$ Masalah picky eating pada anak dapat menjadi persisten hingga lebih dari 2 tahun. ${ }^{25}$ Sebagian besar orang tua pada penelitian ini cenderung mengganggap anaknya sebagai picky eater antara umur 1-2 tahun. Dalam penelitian menemukan $75 \%$ picky eater mulai menolak untuk makan pada tahun pertama kehidupan, berlanjut hingga usia dua tahun, dan setelah itu apabila terus berlanjut akan diikuti dengan berat badan yang kurang. ${ }^{4}$

Perilaku picky eating dapat ditentukan dengan beberapa metode penilaian. Penggunaan metode single item ataupun multiple items dari kuisioner. ${ }^{26}$ Penelitian ini menggunakan salah satu kuisioner yaitu Children Eating Behavior Questionnaire (CEBQ). Kuisioner CEBQ dapat mengidentifikasikan picky eating dan kebiasaan makan anak dengan adanya kategori food avoidant dan food approach karena perilaku picky eating memiliki karakteristik yang berbeda. ${ }^{17,18}$ 


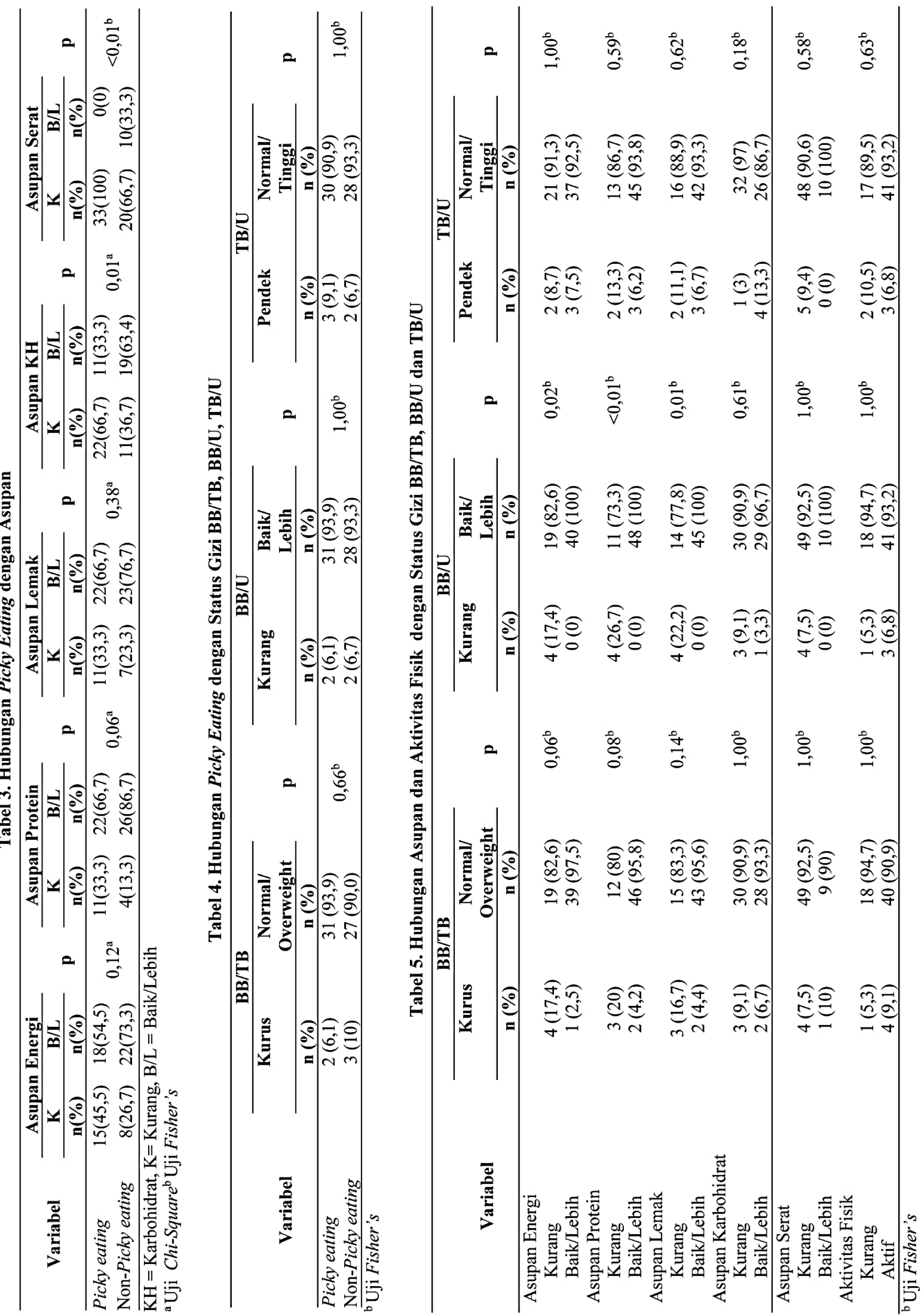


Anak diidentifikasikan sebagai picky eating apabila menunjukkan karakteristik yang khas. Perilaku picky eating seperti mengonsumsi variasi makanan terbatas, jumlah asupan terbatas, makan lama, menolak coba makanan baru, menunjukkan preferensi makanan yang kuat baik makanan kesukaan ataupun tidak, dan menunjukkan sedikit ketertarikan terhadap makanan. ${ }^{26,27}$ Karakteristik tersebut mirip dengan subjek pada penelitian ini yang memiliki kategori menolak mencoba makanan baru, mempunyai preferensi kuat terhadap makanan, dan makan lebih dari 30 menit.

Hasil penelitian ini menunjukkan anak yang picky eating berhubungan dengan asupan serat dan karbohidrat, tetapi tidak berhubungan dengan asupan energi, protein dan lemak. Anak picky eater cenderung kurang asupan sayur, buah, ikan, dan nasi. Namun, mereka mengonsumsi susu, biskuit, wafer, bakso, nugget, ayam, dan makanan digoreng. Rendahnya asupan sayur dan buah yang tinggi kandungan vitamin dan mineral dapat menyebabkan individu tidak memenuhi kebutuhan mikronutrien harian. ${ }^{35}$ Dalam penelitian ini, ada subjek yang mengonsumsi susu hingga 8 botol sehari. Beberapa anak umur 3 tahun yang beberapa picky eater memiliki kebiasaan minum susu dalam volume yang besar. ${ }^{28}$ Konsumsi susu sangat penting untuk kalsium, tetapi kelebihan minum susu dapat menyebabkan penurunan nafsu makan dan asupan makanan lainnya. ${ }^{24}$ Konsumsi susu dianjurkan tidak lebih dari tiga gelas setiap hari. ${ }^{29}$ Pemberian susu pada anak sebagai pengganti makan dilakukan ibu karena takut kebutuhan gizi anak tidak tercukupi sehingga kebutuhan energi, lemak, protein dapat dipenuhi meskipun variasi makanan kurang.

Sebagian besar makanan yang mengandung tinggi serat dan karbohidrat cenderung sedikit diasup. Faktor internal yang mempengaruhi anak tidak menyukai makanan tersebut dikarenakan tekstur yang membuat anak kesulitan saat mengunyah. Ketidaksukaan anak terhadap warna, rasa dan sensitivitas anak terhadap makanan. ${ }^{30}$ Menurut ibu, asupan sayur berwarna hijau tidak menarik bagi anak, rasa yang cenderung pahit, dan jenis makanan yang kenyal, berlendir membuat anak tidak mau mengonsumsi makanan yang disajikan. Selain itu, rasa kenyang sebelum waktu makan disebabkan susu dan snack dapat membuat asupan makan anak menurun.

Jenis makanan yang dikonsumsi anak dapat dipengaruhi lingkungan sebagai faktor eksternal. Anak pra sekolah cenderung suka meniru perilaku makan keluarga dan lingkungan sekitar, sehingga cenderung akan lebih menikmati makanan bervariasi jika anak melihat anggota keluarga juga menikmati makanan bervariasi. ${ }^{5}$ Orangtua secara sadar atau tidak sadar telah menuntun kesukaan makan anak dan membentuk perilaku makan karena orang tua yang menentukan jenis makanan yang akan diasup anak. ${ }^{31}$ Pada penelitian ini, ditemukan makanan yang disediakan oleh ibu tergantung preferensi makanan kesukaan keluarga, sehingga ibu hanya mengenalkan jenis makanan tersebut kepada anak.

Picky eating tidak berhubungan dengan status gizi. Hal ini terkait dengan tidak adanya hubungan picky eating dengan asupan energi, protein dan lemak. Status gizi secara antropometri lebih dipengaruhi asupan zat gizi makro. ${ }^{32}$ Akan tetapi, pada penelitian ini tidak ditemukan adanya masalah zat gizi makro, sehingga picky eating tidak berhubungan dengan status gizi karena asupan makan yang baik. Picky eater cenderung menolak makan di suatu waktu, tetapi pada hari lain akan memakan makanan yang ditolaknya kemarin. ${ }^{33}$ Perilaku tersebut dapat menyeimbangkan kebutuhan zat gizi walaupun tidak dikonsumsi setiap hari dan hal ini tetap memerlukan peranan orang tua. ${ }^{33}$ Penelitian Hapsari menemukan $76 \%$ picky eater berstatus gizi baik dan tidak menemukan adanya hubungan picky eating dengan status gizi. ${ }^{12}$ Meskipun status gizi anak dengan picky eating terkategori baik tetapi konsumsi buah dan sayur yang kurang dapat menyebabkan kekurangan mikronutrien pada anak. ${ }^{34}$

Asupan energi, lemak dan protein berhubungan dengan status gizi $\mathrm{BB} / \mathrm{U}$, tetapi tidak berhubungan dengan status gizi BB/TB dan TB/U. Status gizi TB/U kurang sensitif untuk masalah gizi dalam waktu yang pendek, karena indeks TB/U menggambarkan status gizi masa lalu berkaitan dengan riwayat anak. ${ }^{19} \mathrm{Pada}$ penelitian ini ditemukan sebagian besar anak pendek memiliki riwayat pernah dirawat di rumah sakit karena tipes, panas tinggi, atau dehidrasi. Indeks $\mathrm{BB} / \mathrm{U}$ berdasarkan pada kenaikan berat badan anak seiring pertambahan umur sedangkan indeks BB/TB berdasarkan teori proporsional tubuh yaitu berat badan dengan tinggi badan. ${ }^{34}$ Indeks BB/TB sensitif terhadap perubahan mendadak karena asupan kurang atau sakit. ${ }^{19}$ Berdasarkan hasil statistik indeks BB/TB tidak berhubungan dengan asupan, tetapi terlihat adanya kecenderungan asupan energi dan protein dengan indeks $\mathrm{BB} / \mathrm{TB}(0,05<\mathrm{p}<0,1)$. Status gizi baik terjadi bila tubuh memperoleh cukup zat-zat gizi yang digunakan secara efisien, sedangkan status gizi kurang terjadi bila tubuh mengalami kekurangan satu atau lebih zat-zat gizi esensial. ${ }^{35}$

Kebiasaan makan anak dipengaruhi oleh hubungan antara orang tua atau pengasuh dengan anak melalui pola asuh dalam pemberian makan. Orang tua menggunakan tekanan dan restriksi (pola asuh otoriter) dalam praktik pemberian makan yang non-responsif dapat menyebabkan anak memiliki perilaku picky eating. Pola asuh pengabaian dan permisif juga menggunakan praktik makan non responsif. ${ }^{36}$ Sebaliknya, anak yang diasuh secara demokratif cenderung memiliki kebiasaan positif yaitu menerima 
makanan dan belajar mengenai respon terkait isyarat lapar dan kenyang sehingga anak mengembangkan kebiasaan makan sehat. Pola asuh demokratif menggunakan praktik makan responsif (responsive feeding) ${ }^{36}$ Penelitian ini menunjukkan beberapa anak yang diasuh dengan demokratif tidak mengalami picky eating, sedangkan beberapa anak picky eating diasuh dengan permisif.

Responsive feeding adalah hubungan timbal balik antara anak dan pengasuh dengan komunikasi secara verbal dan non-verbal terkait perasaan lapar dan kenyang yang diikuti respon dari pengasuh. Lima prinsip utama responsive feeding, yaitu menyuapi langsung atau membantu anak makan sendiri, memberi makan perlahan, sabar dan mendorong anak untuk makan, respon terhadap penolakan makan, memberi makan di lingkungan yang aman, dan waktu makan adalah waktu untuk belajar dan mengasihi. ${ }^{36}$ Responsive feeding dapat dilakukan untuk menanggulangi kejadian picky eating karena responsive feeding dapat meningkatkan kemampuan self-feeding anak dan respons terhadap bahasa verbal ibu, melatih anak untuk mengonsumsi makanan keluarga dan makan sendiri (selffeeding) ${ }^{37}$ Selain itu, melatih anak untuk berperilaku makan yang baik, disiplin, dan dapat menghargai makanan dan waktu makan. ${ }^{38}$ Penelitian menunjukkan praktik responsive feeding dapat meningkatkan penerimaan makanan dan kemampuan makan sendiri. ${ }^{39,40}$ Beberapa ibu dalam penelitian ini masih ada yang menggunakan metode jalan-jalan sambil menyuapi anak makan, hal ini memiliki sisi positif dan negatif. Sisi positifnya anak menjadi banyak makan, tetapi tidak membantu anak untuk meningkatkan kemampuan self-feeding. Selain itu, beberapa orang tua cenderung memberikan makanan yang disukai karena kekhawatiran terhadap asupan anak yang sedikit, sehingga anak kurang diberi paparan makanan baru. Beberapa cara untuk mengurangi perilaku picky eating pada anak yaitu tawarkan makanan baru terlebih dahulu saat anak lapar dan menyajikan makanan secara kreatif yang dapat menarik perhatian anak. ${ }^{41}$

\section{SIMPULAN}

Penelitian ini tidak menunjukkan hubungan picky eating dengan status gizi berdasarkan $\mathrm{BB} / \mathrm{TB}$, BB/U dan TB/U. Namun, ditemukan bahwa picky eating berhubungan dengan asupan karbohidrat dan serat kurang. Selain itu, asupan energi, protein, dan lemak memiliki hubungan dengan status gizi $\mathrm{BB} / \mathrm{U}$.

\section{SARAN}

Perilaku picky eating tidak selalu menimbulkan masalah gizi, karena picky eating juga merupakan suatu fase normal. Namun, ibu perlu mencari tahu penyebab picky eating pada anak dan metode pendekatan yang dapat digunakan dan disesuaikan dengan anak.

\section{DAFTAR PUSTAKA}

1. Brown JE. Nutrition through the life cycle. 4th ed. Fluoride. Cengage Learning; 2011. p. 296-309.

2. Xue Y, Lee E, Ning K, Zheng Y, Ma D, Gao H, et al. Prevalence of picky eating behaviour in Chinese school-age children and associations with anthropometric parameters and intelligence quotient. A cross-sectional study. Appetite. 2015;91:248-55.

3. Cooke L, Carnell S, Wardle J. Food neophobia and mealtime food consumption in 4-5 year old children. Int J Behav Nutr Phys Act. 2006 Mar 17;3(14).

4. Northstone K, Emmett P. The associations between feeding difficulties and behaviours and dietary patterns at 2 years of age: The ALSPAC cohort. Matern Child Nutr. 2013;9(4):533-42.

5. Wright CM, Parkinson KN, Shipton D, Drewett RF. How do toddler eating problems relate to their eating behavior, food preferences, and growth? Pediatrics. 2007;120(4):1069-75.

6. Antoniou EE, Roefs A, Kremers SPJ, Jansen A, Gubbels JS, Sleddens EFC, et al. Picky eating and child weight status development: A longitudinal study. J Hum Nutr Diet. 2016;29(3):298-307.

7. Mikhail WZ, Khairy SA, Salem HYHA, Samy MA. Effect of nutritional status on growth pattern of stunted preschool children in Egypt National Nutrition Institute ( NNI ), Cairo, Egypt. Academic Journal of Nutrition. 2013;2(1):1-9.

8. Kwok FYY, Ho YYF, Chow CM, So CYN, Leung TF. Assessment of nutrient intakes of picky-eating Chinese preschoolers using a modified food frequency questionnaire. World $\mathrm{J}$ Pediatr. 2013;9(1):58-63.

9. Fitriani F, Febry F, Mutahar R. Gambaran penyebab kesulitan makan pada anak prasekolah usia 3-5 tahun di perumahan top amin mulya jakabaring palembang tahun 2009. J Publ Ilm Fak Kesehat Masy Univ Sriwij. 2009.

10. Telaumbanua LK. Faktor-Faktor Yang Mempengaruhi Sulit Makan Pada Usia Prasekolah Di TK Islam Nurul Hikmahbantar Gebang Bekasi Tahun 2013 [Skripsi]. Bekasi: STIKES Medistra Indonesia; 2013.

11. Kesuma A, Novayelinda R, Sabrian F. Faktor Faktor yang Berhubungan dengan Perilaku Kesulitan Makan Anak Prasekolah. [Skripsi] Riau: Universitas Riau; 2015.

12. Kusuma HS, Ma'shumah N. Status gizi balita berbasis status pemilih makan di wilayah kerja puskesmas kedungmundu semarang. Dalam: The 2nd University Research Coloquium 2015; 2015. p 184-9.

13. Ekstein S, Laniado D, Glick B. Does picky eating 
affect weight-for-length measurements in young children? Clin Pediatr. 2010;49(3):217-20.

14. Jansen PW, Roza SJ, Jaddoe VW, Mackenbach JD, Raat H, Hofman A, et al. Children's eating behavior, feeding practices of parents and weight problems in early childhood: results from the population-based Generation R Study. Int J Behav Nutr Phys Act. 2012;9(1):130.

15. National Institute for Health Research \& Development. Riset Kesehatan Dasar (National Health Survey). Minist Heal Repub Indones. 2013;(1):1-303.

16. Dinkes Kota Semarang. Profil Kesehatan Kota Semarang Tahun 2013. Dinas Kesehat Kota Semarang; 2014:72.

17. Wardle J, Guthrie CA, Sanderson S, Rapoport L. Development of the children's eating behaviour questionnaire. J Child Psychol Psychiatry. 2001;42(7):963-70.

18. Tharner A, Jansen PW, Jong JCK, Moll HA, Ende J Van Der, Jaddoe VW V, et al. Toward an operative diagnosis of fussy / picky eating : a latent profile approach in a population-based cohort. International Journal of Behavioral Nutrition and Physical Activity. 2014;1-11.

19. Kementerian Kesehatan RI. Keputusan Menteri Kesehatan Republik Indonesia, No.1995/Menkes/SK/XII/2010 tentang Standar Antropometri Penilaian Status Gizi Anak; 2011.

20. Gibson RS. Principles of nutritional assessment. 2nd ed. New York: Oxford University Press; 2005. 208 p.

21. Hardinsyah, Riyadi H, Napitupulu V. Kecukupan Energi, Protein, Lemak dan Karbohidrat. Dalam Widyakarya Nasional Pangan dan Gizi X; 2015.

22. Bingham DD, Collings PJ, Clemes SA, Costa S, Santorelli G, Griffiths P, et al. Reliability and validity of the Early Years Physical Activity Questionnaire (EY-PAQ). Sports. 2016;1-14.

23. Xue Y, Zhao A, Cai L, Yang B, Szeto IM., Ma D, et al. Growth and development in Chinese preschoolers with picky eating behaviour: a crosssectional study. PLoS One: 2015; 10(4).

24. Centre for Population Health. Caring for children birth to 5 years (food, nutrition and learning experiences). NSW Ministry of Health. p. 72-77.

25. Mascola AJ, Bryson SW, Agras WS. Picky eating during childhood: a longitudinal study to age 11 years. Eat Behav. 2010;11:253-7.

26. Taylor CM, Wernimont SM, Northstone K, Emmett PM. Picky / fussy eating in children: Review of definitions, assessment prevalence and dietary intakes. Appetite. 2015;95:349-59.

27. Jacobi C, Schmitz G, Agras WS. Is picky eating an eating disorder? Int J Eat Disord. 2008;41:626-34.
28. Taylor CM. Northstone K, Wernimont SM, Emmet PM. Macro- and micronutrient intakes in picky eaters: a cause for concern? Am J Clin Nutr: 2016.

29. Heart Foundation. Kids at Play-Active Play and Eating Well Project. [Internet]. 2007. [cited 2018 Mar 9]. Available from: http://www.dhhs.tas.gov.au

30. Van der Horst K, Deming DM, Lesniaukas, Carr BT, Reidy KC. Picky eating : Associations with child eating characteristics and food nntake. Appetite. 2016; 103: 286-293.

31. Jones LR, Steer CD, Rogers IS, Emmett PM. Influences on child fruit and vegetable intake : sociodemographic, parental and child factors in a longitudinal cohort study. Public Health Nutr. 2010; 13: 1122-1130.

32. Arisman. Buku ajar ilmu gizi : gizi dalam daur kehidupan. 2nd ed. Jakarta: Penerbit Buku Kedokteran EGC; 2008.

33. Hunter JG, Cason LK. Picky Eaters. [Internet]. 2008. [cited 2018 Mar 9]. Available from: https://hgic.clemson.edu/factsheet/picky-eaters/

34. Supariasa IDN, Bakri B, Fajar I. Penilaian status gizi. 1st ed. Jakarta: Penerbit Buku Kedokteran EGC; 2001: 56-58.

35. Almatsier, S. Prinsip dasar ilmu gizi. Jakarta : Penerbit PT Gramedia. Pustaka Utama; 2009.

36. Harbran J, Booley S, Najaar B, Day CE. Responsive feeding: establishing healthy eating behaviour early on life. South Africa Journal of Clinical Nutrition. 2013; 26(3)(Supplement): 141-149.

37. Aboud FE, Akhter S. A cluster-randomized evaluation of a responsive stimulation and feeding intervention in Bangladesh. Pediatrics. 2011;127: 1191-1197.

38. Unit Kerja Koordinasi Nutrisi dan Penyakit Metabolik. Rekomendasi Praktik Pemberian Makan Berbasis Bukti pada Bayi dan Batita di Indonesia untuk Mencegah Malnutrisi. Rekomendasi Praktik Pemberian Makan Berbasis Bukti pada Bayi dan Batita di Indonesia untuk Mencegah Malnutrisi. Ikatan Dokter Anak Indonesia; 2015.

39. Bentley ME, Wasser HM, Creed-Kanashiro HM. Responsive feeding and child undernutrition in low and middle income countries. Journal of Nutrition. 2011; 141: 502-507.

40. Aboud FE, Shafique S, Akhter S. Responsive feeding intervention increases children's self-feeding and maternal responsiveness but not weight gain. Journal of Nutrition. 2009; 139: 1738-1743.

41. McMaster Children's Hospital. Still a picky eater? Helping children who are selective eaters. Hamilton Health Sciences: 2012. 